\title{
APOLOGY AND COMPENSATION STRATEGY ON CUSTOMER FORGIVENESS AND NEGATIVE WORD OF MOUTH
}

\author{
Resekiani Mas Bakar ${ }^{1}$, Nurul Hidayati ${ }^{2}$, Inastuti Retno Giffani ${ }^{3}$ \\ ${ }^{123}$ Psychology Faculty, Universitas Negeri Makassar \\ A.P. Pettarani Street, Makassar, 90222, South Sulawesi, Indonesia \\ *Corresponding author email: resekiani_masbakar@unm.ac.id
}

\begin{abstract}
The service provider could not totally guarantee the service process without any failure at all. This study aims to measure the influence of service recovery strategy towards customer forgiveness and negative wordof-mouth (WOM) as the effect of service failure. The service recovery strategy is performed in three types of vignette: apology, compensation, and apology-compensation. Vignette was given to 94 participants who have encountered service of airline. The result of ANOVA shows that apology compensation achieves the highest score relates to forgiveness. The interesting result of this study shows that even the customers forgive the service provider due to the service failure they did, this cannot diminish the intention of negative WOM. This study offers an implication to the company in order to pay attention regarding the compensation and the spread of negative WOM to the other customers.
\end{abstract}

Keywords: Apology, compensation, forgiveness, negative word-of-mouth, service recovery strategy

\section{Introduction}

Transportation mobility is one of the propo-nent factors in society's activities nowadays, especially in business and travel. This is due to interaction and need, not only occur in one place, but also intercity, inter-island, and even overseas. The use of air transportation becomes the right de-cision to support vast distance efficiency because it can diminish time and effort. Aviation industry in Indonesia is growing rapidly to offset the number of demands. The information from the General Directorate of Air Transportation Indonesia stated that in 2017 , there were 495,789 flights, both arrivals and departures. This proportion increased in 2018 to 541,185 flights. This data includes domestic and international flights. Similarly, for passangers of air transportation raised from 20.6 million in 2017 to 27.7 million in 2018 (Direktorat Jenderal Perhubungan Udara, 2019). Therefore, this high demand on flights should be balanced with maximum service from aviation industry in order to maintain the customer experience in using air transportation.

The great demand on flight schedules forces several aviation industries to compete each other in providing possibly both quantity and quality in service as many and well as to customers. Service awarding in the context of consumers' behavior offers the affective effect towards the transaction agent, especially for the customers (Wanke, 2008). The maximum service awarding will give a pleasant experience and emotional influence. Furthermore, this experience enables the customer to make an evaluation as well as the recommendation in the broader society (Maxham \& Netemeyer, 2002).

Every service provider tries to meet and exceed the expectation of their customers (Lai \& Chou, 2015). The service offered by the company will represent a vision, missions, and values of the organization and the customer will assess the credibility of the company. Every business aims to offer the best service to its customers because customer satisfaction is used as the standard in measuring the company success, so if this target can be reached, the company will gain many benefits in their competition with the other business (Rashid \& Ahmad, 2014). Moreover, customer satisfaction will determine customer trust and attitude for the next transaction (Ranaweera \& Prabhu, 2003).

In reality, the perfect service for customers is not always easily achieved (Choi \& La, 2013). The process in creating maximum service sometimes encounters several obstacles, which cannot be avoided by the producers and cause service failure. In the context of air transportation, service failure is usually related to flight schedule delay. It can be caused by several reasons such as weather condition, airport congestion, and airspace congestion (Deshpande \& Arikan, 2012). This problem occurs when service provider cannot fulfill their customer expectation. Although there were some studies have explored the recovery strategy towards customer forgiveness, it had some limitations regarding its implication to consumer's WOM. Whether the service failure can be tackled 
solely either by apology or compensation, or combining between apology and compensation. Furthermore, if the customer forgives the service provider, will the customers guarentee the confidentiality of unpleasant experience they have encountered?.

The service provider or firm should realize that the customer is a valuable asset for business development in the future. Service failure is inevitable, therefore the quality of recovery becomes crucial (Lai \& Chou, 2015). Service failure can be tackled by a specific treatment, which is called a service recovery strategy. This recovery method plays an important role in maintaining the existing relationship with customer after the service failure. In today's competitive market environment, creating new customers requires more efforts than preserving the old customers. In several studies, customer willingness to give the recommendation about the product or service will increase $15 \%$ bigger after receiving the appropriate service recovery from the company than the customer who does not receive the service recovery. Therefore, the service recovery strategy from the service provider will determine their commitment to their customer relationship for long period.

This study covered the context of aviation industry in Indonesia and focused the research scope on the departure schedule accuracy. During the service process, we obtained data that there were $54.3 \%$ of total participants admitted the experience of delay and $2 \%$ of them were served by the unfriendly flight attendants. In dealing with service failure, the airplane company usualy offer some strategies, such as providing compensation (28\%), apology (7\%), and do nothing $(65 \%)$. On the other hand, customers who received this inconvenience expressed the different responses. $40.4 \%$ participants stated that the service recovery from the airline company was appropriate, while $59.6 \%$ of them said that it was inappropriate. Hence, the company must prepare their readiness in coping the service failure and providing the suitable recovery service for the customer.

Several studies showed that companies that use apology strategy to their customers can return the customer satisfaction more than those that do not apply. However, compensation that has been given after the service failure enables the customers perceive equality (Kwon \& Jang, 2012). Giving compensation in the context of service failure corresponds with a social exchange theory where a social relationship is similar to an economic transaction, therefore, feeling loss of service failure can be overcome by offering the compensation.

The service providers should be aware that the impact of consumer's behavior can be more detri- mental as time passes by (Wirtz \& Lovelock, 2018). Some customers may show other responses when encountering the inconvenience, instead of forgiving. Customer defection can be more dangerous and leads to the decline of customer quantity and the company revenue. The customer will spread the negative WOM to other customers when encountering service failure. The information contained in WOM is able to shape people perspective due to service quality of certain companies without direct interaction.

Information spreading due to the product or service provides several benefits, like the ease and speed in the collection of information, discussion regarding products and service, the exchange of instant feedback and its permanent record (Nunes \& Lucian, 2014). Thus, the emerge of WOM was regarded as giving a lot of advantages for consumers and it leads to the big role of WOM itself to the company credibility. The advance of technology also plays the important role. WOM nowadays do not only happen in real physical interaction, but also in online communities.

Voyer and Ranaweera (2015) in their research found that the higher customer involvement in WOM, the bigger effect that WOM will cause. In contrast, the better relationship between customer and service provider, the less negative impact that WOM will be. Those negative impacts of WOM can spread the influence to several aspects, such as the company revenue and psychological effect.

The previous study examined the perceived justice as one of several methods in overcoming the service failure among the United States college students (Choi \& Choi, 2014). Perceived justice consists of three elements: distributive justice, interactional justice, and procedural justice. Distributive justice is the company's effort in providing service recovery by offering a sale or refund. Procedural justice related to the service provided by the company during the service recovery process, like performing appropriate treatment in overcoming the customer complains. While interactional justice refers to the attitude of the organization's employee during their interaction with the customer, like politeness. The result of this study proved that procedural and interactional justice significantly affected the customer affection after encountering service failure, however distributive justice merely affected when the customer spent more budget due to the service.

The appropriate service recovery of the company can minimize the negative WOM spreaded by customers. This study relates to an experimental study conducted by Casidy and Shin (2015) that applied three kinds of service recovery strategy: apology, 
compensation, and hybrid method (apology and compensation) on direction of harm and no direction harm to negative WOM.

There are three responses from customers towards service failure: public action, private action, and no action or forgiveness (Wirtz \& Lovelock, 2018). The customer who prefers to public action will do the action to the company or service provider, the third party, and even to the law institution. On private action, the customer chooses to stay away and will not use the product or service from the company and spread the negative WOM, while for no action; the customer does not do anything and forgive the producer. The customer can perform one of these actions or combine several actions.

An individual response to the inconvenience from service failure does not always cause aggressive behavior like revenge and negative WOM (Aquino, Tripp, \& Bies, 2006). Most researchers found that the customers prefer to not do any action and forgive the company or service provider who performs the service failure (Wirtz \& Lovelock, 2018). Forgiveness is the internal behavior from individual to discard their anger, hatred, and revenge willingness to people or institution who have done the service failure (Bies, Barclay, Tripp, \& Aquino, 2016). The previous study obtained the result that customer forgiveness enables the organization to restore and strengthen its connection with customers (Joireman, Grégoire, \& Tripp, 2016).

\section{Service Recovery Strategy}

The service recovery strategy constitutes an action performed by an organization to respond the service failure that consists of improvement, change, and replacement in order to return the customer satisfaction and maintain the good relationship (Miller, Craighead, \& Karwan, 2000; Park \& Park, 2016; Rashid \& Ahmad, 2014). In its implementation, the service recovery strategy should be proactive, wellplanned, and empowering all the employees of the company to perform the best service recovery (Wirtz \& Lovelock, 2018). This effort is aimed to decrease the draw-backs from service failure such customer trust and convenience (Chahal \& Devi, 2015).

The service recovery system can be undertaken through several variations, such as apologies to customer, compensation, the feedback from the customer as service improvement and train the employees in order to offer a great service. This method is regarded as being essential for several companies in rebuilding customer trust and other positive behavior (Casidy \& Shin, 2015).
Previous researches explained about several methods used in offering service recovery strategy. There are five ways organizations can undertake to tackle service failure: apology, immediate correction, empathy, compensation, and continuous concern (Park \& Park, 2016). For compensation, empathy, and continuous concerns strategy refer to the recovery strategy for the customer who experiences the material damage or costs, while apology and immediate correction for the angry customer. Customer dissatisfaction does not merely come from service failure itself, but other inappropriate treatments from the service provider, such as the awareness due to service failure that has been done, explanation about the cause of service failure, and service recovery quality that offered to the customer. Furthermore, time used in providing the service recovery to customer is essential (Jin, Nicely, Fan, \& Adler, 2019). This study found that employees who gave the recovery strategy in 30 minutes after service failure gained more customer satisfaction that who did in two hours.

The common types of service recovery strategy are apology and compensation award. Apology is a compensation strategy which psychologically can diminish the negative behavior tendencies caused by service failure (Sengupta, Ray, Trendel, \& Vaerenbergh, 2018). While compensation is return the customer money.

\section{Word-of-Mouth}

Several studies defined word-of-mouth communication as a type of informal communications among the customers as the evaluation or judgment due to their experience with the product or service from the particular company (Casidy \& Shin, 2015; East, Hammond, \& Lomax, 2008; Vázquez-Casielles, Suárez-Álvarez, \& del Río-Lanza, 2013). Therefore, customer satisfaction becomes the fundamental factor in WOM (Özdemir, Tozlu, Şen, \& Ateşoğlu, 2016).

WOM consists of two types: the positive WOM and the negative WOM (Vázquez-Casielles et al., 2013). The negative WOM tends to give the negative information from the failure of a particular service or product. The negative WOM can broadly affect the consumer behavior, especially for decision making to repurchase the product or service. The existance of negative WOM as the impact of service failure in this competitive world can be avoided by the service provider. The negative WOM can influence the consumer's satisfaction through the decline of their expectation of the product or service (Shi, Tang, Zhang, Gao, \& Zhu, 2016). These two types of WOM come from customer experience and understanding of the brand (Casidy \& Shin, 2015). 
Based on the explanation above, we develop the following hypothesis:

$H_{1}$ : Service recovery strategy will positively influence the customer forgiveness. Apology-compensation strategy will perform the highest customer forgiveness, compared with apology strategy and compensation strategy.

$\mathrm{H}_{2}$ : Service recovery strategy will influence the decrease of negative WOM. Apology-compensation method will perform the lowest negative WOM, compared with apology strategy and compensation strategy.

\section{Research Method}

The aim of this experimental study was to investigate the effect of service recovery strategy (apology, compensation, or apology-compensation) on customer forgiveness and negative word of mouth. The research questions of this study:

1 . Is there any differences between apology, compensation, and combining between apo-logycompensation strategy to enhance the customer forgiveness?

2. Which kind of service recovery strategy is more influential on customer forgiveness?

3. Is there any differences between apology, compensation, or combining between apolo-gy-compensation strategy to decrease the customer intention to spread the negative WOM?

4. Which kind of service recovery strategy is more influential on negative WOM?

The conceptual framework of this study presented in Figure 1.

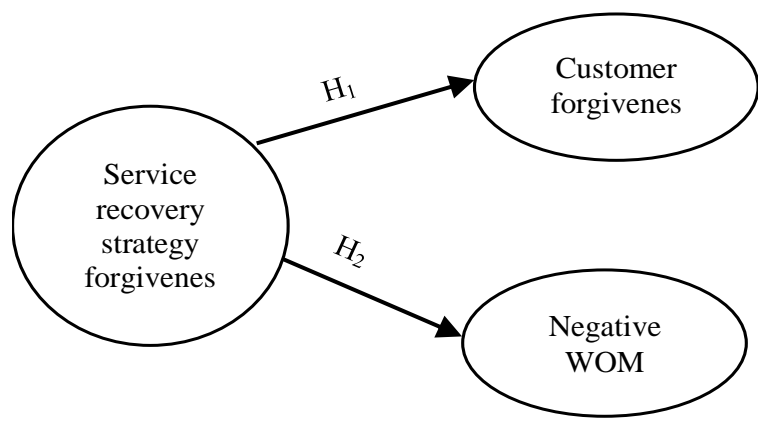

Figure 1. Conceptual framework

\section{Variable and Experimental Design}

This study measured the influence of service recovery strategy towards the customer forgive-ness and the intention of negative WOM. There were three variations of service recovery strategy in this experiment: apology versus compensation versus apology- compensation. In additional, we also applied the forgiving trait as the control variable in this experiment to ensure the result is only caused by the difference of service recovery strategy. Experimental design of this study was post-test only between-participants design.

\section{Participants}

Research sample was obtained through the experimental study. The initial sampling techni-que used recrutiment method. The recruitment process was executed by conveying the announce-ment. The participants who have confirmed their involvement in this experiment were placed randomly into three experiment groups. Participants on this study focused on people who had at least twice experiences using air trasnportation. The total participants involved in this study were 130 people, but only 94 were analyzed. 26 participants were exclued in this study due to the incompatibility in manipulation check. This study involved 94 participants and consisted of both male $(41.5 \%)$ and female $(58.5 \%)$. The participants consisted of three experiment group: apology group $(N=26)$, compensation group $(N=28)$, and apologycompensation $(N=40)$. The partici-pants in this study come from Makassar City, Indonesia. The age of participants ranged from $18-52$ years old (14\% of age 21 years old). The participants come from several occupation back-grounds, such as college students (30\%), civil servants (11\%), employees (13\%), entrepreneurs $(16 \%)$, and freelancers (10\%). The educational background of participants consisted of: Senior High School (14.9\%), Bachelor Degree (77.7\%), Magister Degree (6.4\%), and Doctoral Degree (1\%). The specific character of respondents in this study is airline consumers who have experienced minimum twice using the airplane.

\section{Procedures}

This study used between participant experiment designs which divided participants into three groups: apology group, compensation group, and apologycompensation group.

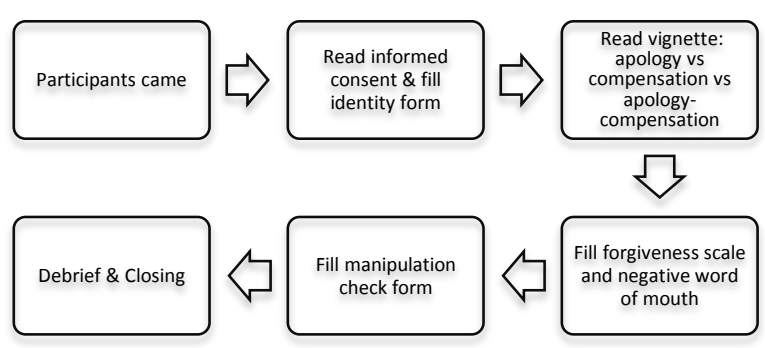

Figure 2. Experiment procedure 
The participants came and entered the experiment room. In the beginning, the participant read the informed consent sheet and then filled the identity form. After completing the identity, the participant was given the service failure vignette and asked to imagine that condition. All groups obtained the similar service failure vignette. The difference was in the service recovery vignette:

\section{Apology Vignette}

"I feel so sorry for this inconvenience situation. As the staff of this airline company, I really want to apologyize for making you dissatisfied. I really feel guilty because you cannot departure as the schedule".

\section{Compensation Vignette}

"The airline staff informed you the cause of the departure delay and offered the free voucher to the next trip. This free ticket had a similar price with the previous one. The staff also gave the free accommodation in five-star hotel, nearby the airport and free meals allowance".

\section{Apology-Compensation Vignette}

"I feel so sorry for this inconvenience situation. As the staff of this airline company, I really want to apologies for making you dissatisfied. I really feel guilty because you cannot departure as the schedule. The airline staff informed you the cause of the departure delay and offered the free voucher to the next trip. This free ticket had a similar price with the previous one. The staff also gave the free accommodation in five-star hotel, nearby the airport and free meals allowance".

After reading the vignette, the participants were asked to fill the forgiveness scale and the negative WOM scale. In the end of the experiment, the participants complete the manipulation check and forgiving trait scale.

\section{Material}

\section{Informed Consent}

The informed consent form is the involvement agreement sheet from participants to enroll in particular studies without any forces. This consent comprises research purpose and procedure, as well as participant right to join or not in the research. Responsibility from the researchers towards the negative or detrimental effects that might be caused by the study was explained in the informed consent sheet.

\section{Service Failure Vignette}

The vignette used in this study referred to the experiment by Casidy and Shin (2015). In the beginning, the vignette was tested to several participants. This trial was performed to measure participants' ability in understanding the vignette.

On the service failure vignette, the participants were served a story and asked to imagine the event from that story. Service failure vignette depicted the postponement of the airplane company, whereas the customer have preapared since long time ago to attend the family gathering in the hometown. The vignette explained the delay of airplane departure from a certain company and there were no other airplanes that could be used. The only one activity that participants can do was waiting until the company announced for the new schedule.

\section{Service Recovery Strategy Vignette}

Service recovery strategy vignette consisted of three types: apology, vignette, compensation vignette, and apology compensation vignette, which supplied to three groups. The apology vignette comprised the apology from the airline staffs to the customer due to departure postpone. Compensation vignette comprised the information about the recoupment for a free ticket to a certain destination to the customers. While apology-compensation vignette gave both the apology and compensation from the airline crew to the customers (Casidy \& Shin, 2015).

\section{Forgiveness Scale}

Customer forgiveness was conducted after the service recovery strategy vignette in every group. The scale consists of two items. The answer responses in the scale ranged from 1 (Strongly Disagree) to 5 (Strongly Agree). The forgiveness scale in this study was adapted from theprevious study and has been shown to have good internal consistency $\alpha=0.80$ (Aquino, Tripp, \& Bies, 2001). For example, one of the items in this study was: "I forgive this airline company due to the failure they did".

\section{Negative WOM Scale}

The assessment for customer negative WOM rate was conducted after the service recovery strategy vignette in every group. The negative WOM scale consists of three items with the answer responses in the scale ranged from 1 (Strongly Disagree) to 5 (Strongly Agree). Negative WOM scale in this study was adapted from the previous study. The scale has been shown to have good internal consistency $\alpha=$ 
0.91 (Grégoire, Tripp, \& Legoux, 2009). For example, one of the items in this study was: "I will inform other people to not use this company's service anymore".

\section{Forgiving Trait Scale}

Forgiving trait is a control variable in this study. It consists of five questions and the answer responses used the Likert style, ranged from 1 (Strongly Disagree) to 5 (Strongly Agree). This scale was adapted from the previous study. The scale has been shown to have good internal consistency $(\alpha)=0.90$ (Blodgett, Hill, \& Tax, 1997). One of the items in this scale was: "I can easily forgive and forget the past event which was an insult".

\section{Manipulation Check Sheet}

Manipulation check sheet consists of one item. The item was: "from the vignette you have read, what the strategy of recovery was?" The answer options in manipulation check consist of three options: (a) apology, (b) giving the compensation, (c) apology and giving the compensation.

\section{Result and Discussion}

\section{Result}

\section{Manipulation Check}

130 participants have agreed to involve in this experiment. From those participants, there were 36 who cannot be involved in data anlysis process because of the discrepancy between menipulation check form and the received manipulation condition. Therefore, there were only 94 participants data could be processed into further analysis.

\section{Forgiving Trait}

The test analysis shows that there was no difference in forgiving trait level on each group, $F$ (2.93) $=2.125, p>0.05$. Participants in all groups have the similar forgiving trait degree. Mean of this variable in apology group $\left(M_{\text {apology }}=3.07, S D=0.44\right)$ did not show the significant gap with compensation group $\left(M_{\text {compensation }}=3.25, S D=0.48\right)$ and apology compensation group $\left(M_{\text {apology compensation }}=3.34, S D=0.55\right)$.

\section{Service Recovery Strategy on Forgiveness}

ANOVA test is used in this study to examine the influence of customer forgiveness as a dependent variable and service recovery strategy (apology, compensation, and apology compensation) as an indepen- dent variable. This study proves that three kinds of service recovery strategy significantly influenced to customer forgiveness, $F(2.93)=5.071, p<0.05$. The highest mean of service recovery strategy effect is achieved by apology compensation group ( $M_{\text {apology }}$ compensation $=3.67, S D=0.66$ ), compared with two other groups $\left(M_{\text {apology }}=3.15, S D=0.64 ; M_{\text {compensation }}=3.28\right.$, $S D=0.78)$. The ANOVA test supported the first hypothesis in this study. Respondents from apologycompensation group show the highest level of forgiveness. The mean of service recovery strategies on customer forgiveness is presented in Figure 3.

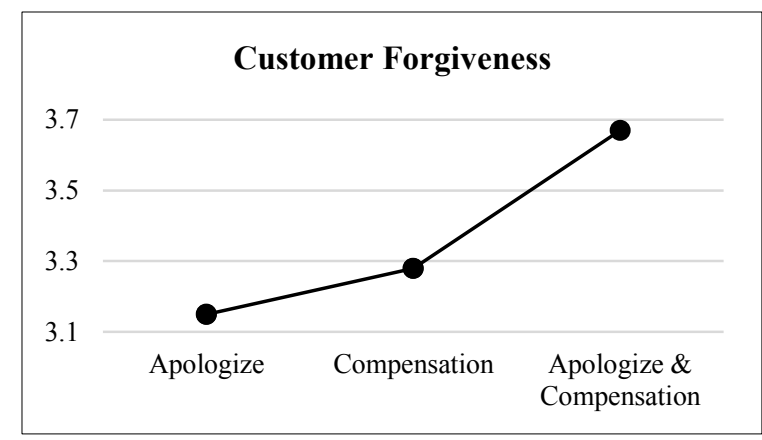

Figure 3. Service recovery strategies on customer forgiveness

\section{Service Recovery Strategy on Negative WOM}

The measurement of the service recovery strategy towards participants' tendency in negative WOM used ANOVA test. This study found that there was a significant difference of service recovery strategy on negative word of mouth, $F(2.93)=3.612, p$ $<0.05$. The highest level of negative WOM is in apology compensation group $\left(M_{\text {apology compensation }}=3.13\right.$, $S D=0.48)$, then two other groups $\left(M_{\text {apology }}=2.81, S D\right.$ $\left.=0.48 ; M_{\text {compensation }}=3.06, S D=0.51\right)$. The result of this study partially supported the second hypothesis. Respondents from apology compensation group showed the higher tendency in negative WOM than two other groups. Mean of service recovery strategies on negative WOM are presented in Figure 4.

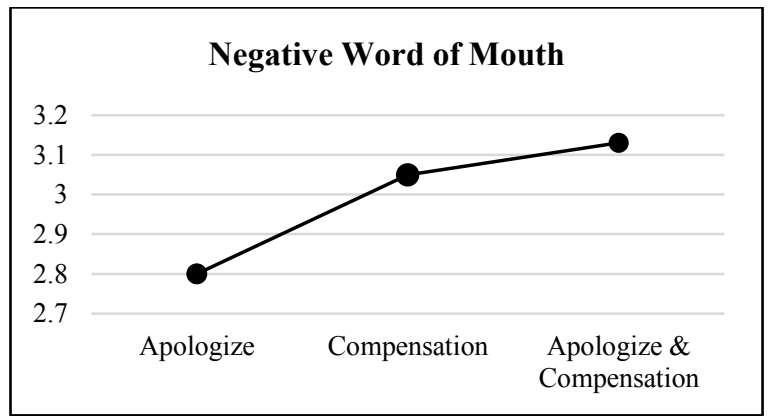

Figure 4. Service recovery strategies on negative WOM 


\section{Discussion}

This study examines the customer forgiveness and negative WOM by using three service recovery strategy variations: apology, compensation, and apology-compensation. This experiment study shows that service recovery strategy awarding influenced the customer forgiveness. This study finds that the highest forgiveness tendency was obtained by the apologycompensation strategy.

Based on participant data on forgiveness scale, it shows that the participants in apology compensation group assessed "agree" (37.5\%) to forgive the airline company for the inconvenience that have occurred. However, more participants choose not to forgive the company failure in apology group (26.9\%). This finding proves that apology strategy itself is not enough to recover the service failure. When participants are asked to assess their willingness to keep using the airline in the future, apology-compensation groups show their agreement $(57.5 \%)$, while the compensation groups tend to show their doubt feeling (39.3\%).

The previous study proved that the mixed service recovery by combining several ways (for example using apology and compensation) can offer more influences than using only the apology or compensation (Maxham \& Netemeyer, 2002). The result of the study is similar to the result of data analysis in this study that finds apology compensation groups gain the highest score. Another study on the airline company also reveals that suitable service recovery from the service provider can spread the positive influences, either for the customer or the company itself (Park \& Park, 2016). This strategy is regarded as it can restore the customer satisfaction and avoid the detrimental behavior.

During the service process, the consumer's justice perspetive and customer satisfaction were strongly influencing by the value of the service process. When the conflict occurs, apology can be used as a social tool in decreasing the tension and bringing up the apology as well (Fehr \& Gelfand, 2010). For the interpersonal context, apology can be used to repair the relationship and restore the balance between one party and other parties. While for the organizational context, apology can be applied to repair the interpersonal relationship among the employees, improve the consumer's experience, and influence the leader's effectivity (Liao, 2007; Tomlinson, Dineen, \& Lewicki, 2004; Tucker, Turner, Barling, Reid, \& Elving, 2006). However, the apology can be succed or failed. These likelihoods are caused by the difference in human's ability to understand the context of apology.
Besides apology, there is another variable involved in customer forgiveness. The compensation strategy has been mentioned in both qualitative and quantitative reasearch in several fileds, such as psychology, sociology, and law as the fundamental component during forgiveness (Lazare, 2007; O'Hara, 2002). Compensation used as another form of apology to improve the negative effect of organizational injustice (Okimoto \& Tyler, 2007). Apology and compensation in the context of service recovery are applied based on justice principle (Tax, Brown, \& Chandrashekaran, 1998). Justice principle in compensation relates to the reward from the inconvenience condition caused by service failure. The principle applied in offering compensation lies on the fairness and exchanging process during the service. The fairness in exchanging process represents the meaning of compensation that serve the similar amount with service failure that the participants have encountered.

The result of this study has proved that apology and compensation are the most effective strategy to build customer forgiveness, compared with two other strategies: apology or compensation only. This mechanism can be explained by self-construal theory. The effectivity of service recovery strategy is caused by the customer's self construal (Fehr \& Gelfand, 2010). Self-construal is the customer's perspective towards themselves as the different part with the service provider. The customer who performs the high selfconstrual will focus on economic exchange and their rights, instead of the emotional relationship with service provider. Furthermore, the consumer who has no close relationship with the service provider will perform the complaining attitude and behavior by asking for the retribution relates to the service failure that customer has experienced. The previous study found that independent self-construal positively influence the compensation, compared with the individual with less independent self-construal.

The participants involved were the consumers from several airplane companies. The vignette used in this experiment does not mention the name of particular airplane companies, so it does not inflict the closeness or any influences to the respondents. The participants does not show the emotional dependency with the airplane as well, so the apology and compensation strategy are regerded as the equal service recovery with the inconvenience felt by the customers.

The second hypothesis of this study is partially proved. It is the interesting result on the one hand, this study shows that there is a different influence of three service recovery strategy variations towards negative 
WOM. Another interesting result of this study shows that even apology compensation group achieves the highest score on forgiveness, but this strategy could not avoid them to spread the negative WOM. Apology compensation group shows the biggest level of negative WOM than two other groups: the apology group and the compensation group.

WOM is the essential information for the company in spreading and influence their service quality to other consumers. Based on the Equity theory, the organization can maintain the positive recommendation by fearly treating their customers when the service failure occurs (Seiders \& Berry, 1998). Participants' data on negative WOM scale showed that all the experiment groups gave the same response in spreading the information regarding the service failure they have experienced. $37.5 \%$ of total participants in apology-compensation group chooses to agree. However, when participants are asked to assess their tendency to upload the service failure in social media, the apology-compensation group shows more disagreements (48\%), while the compensation groups tend to show their agreement (28.6\%). These findings show that negative WOM in apology compensation group merely done by the personal interaction in face to face, not by using social media in large scale.

The result of this study might be caused by several factors, such as apology and compensation performed in this study was regarded cannot fulfill the customer's expectation, at the same time, although the consumers have obtained the apology and compensation, consumers tend to spread the service failure experience to other consumers. The service recovery served by the service provider occurs in customer's out of control. The participants have no control in determining what kinds of the appropriate compensation for them, therefore the participants cannot do anything and finally accept all the condition caused by service failure. Hence, the possible actions can be done in participants' control is spreading the negative WOM, although it merely occurs in face-to-face relationship.

The service recovery strategy cannot diminish the personal intention to spread the negative WOM to the service provider. Previous study found that negative WOM is caused by the dissatisfaction, whether for the product or service (East et al., 2008). The customer may resist the service recovery if they feel apology and compensation awarding from company cannot afford to diminish the negative WOM tendency, thus the consumers will stay spreading the negative WOM to other consumers due to the service failure they encountered.

\section{Conclusion and Implications}

This study finds significant differences effect of service recovery strategy on customer forgiveness. The service recovery of apology and compensation strategy significantly affect to customer forgiveness, compared to apology or compensation only. This study also finds significant differences effect of service recovery strategy on negative word of mouth. However, apology-compensation strategy shows the greatest proportion to the customer intention of negative WOM. These findings reveal the different result, that even the service recovery is able to generate forgiveness, this condition cannot avoid the spread of negative WOM among the society.

This study result showed that the most appropriate service recovery strategy is combining both the apology and compensation strategy. Service failure is sometimes inevitable, therefore the strategy to overcome the failure is strongly required as well as avoiding aggressive behavior from the customer who feels dissatisfied from service. Another important factor that must be noticed is the precise compensation due to the service failure in order to keep the customer satisfaction and loyalty to repurchase the product or service. The influence of collectivist-individualist culture can be applied as the mediation variable for the future study as well. The result of this study also offers the implication for the company to minimize mistakes when providing the service. When the service failure occurs, the service recovery cannot avoid the customer to spread the negative WOM to other customers.

This experiment used the airline context, so it is really expected for the next researchers to use other industries because the different kinds of service industry enable the more variant people responses and tendencies. Another focus is vignette used in this study. The next research can apply another method, like video or real actor in achieving the different result. Other individual factors that influence the apology and information spread are personality types, sex, and cultural background. These variables can be used in the next research.

\section{References}

Aquino, K., Tripp, T. M., \& Bies, R. J. (2001). How employees respond to personal offense: The effects of blame attribution, victim status, and offender status on revenge and recon-ciliation in the workplace. Journal of Applied Psychology, 86(1), 52-59. https://doi.org/10.1037/00219010.86.1.52. 
- (2006). Getting even or moving on? Power, proce-dural justice, and types of offense as predictors of revenge, forgiveness, reconciliation, and avoidance in organizations. Journal of Applied Psychology, 91(3), 653-668. https://doi.org /10.1037/0021-9010.91.3.653.

Bies, R. J., Barclay, L. J., Tripp, T. M., \& Aquino, K. (2016). A systems perspective on forgive-ness in organizations. Academy of Management Annals, 10(1), 245-318. https://doi.org/10.1080/19416 520.2016 .1120956 .

Blodgett, J. G., Hill, D. J., \& Tax, S. S. (1997). The effects of distributive, procedural, and interactional justice on postcomplaint beha-vior. Journal of Retailing, 73(2), 185-210. https://doi.org/10. 1016/S00224359(97)90008.

Casidy, R., \& Shin, H. (2015). The effects of harm directions and service recovery strategies on customer forgiveness and negative word-of-mouth intentions. Journal of Retailing and Consumer Services, 27, 103-112. https://doi.org/10.1016/ j.jretconser.2015.07.012.

Chahal, H., \& Devi, P. (2015). Consumer attitude towards service failure and recovery in higher education. Quality Assurance in Education, 23(1), 67-85. https://doi.org/10.1108/QAE-072013-0029.

Choi, B., \& Choi, B. J. (2014). The effects of perceived service recovery justice on custo-mer affection, loyalty, and word-of-mouth. European Journal of Marketing, 48(1), 108-131. https://doi. org/10.1108/EJM-06-2011 0299.

Choi, B., \& La, S. (2013). The impact of corporate social responsibility (csr) and customer trust on the restoration of loyalty after service fail-ure and recovery. Journal of Services Marke- ting, 27(3), 223-233. https://doi.org/10.1108/088760 41311330717.

Deshpande, V., \& Arikan, M. (2012). The impact of airline flight schedules on flight delays. Manufacturing and Service Operations Mana-gement, 14(3), 423-440. https://doi.org/10.1287/msom. 1120.0379 .

Direktorat Jenderal Perhubungan Udara. (2019). Lalu Lintas Angkutan Udara. Retrieved March 3, 2019, from http://hubud.dephub.go.id/?id/llu/ index/filter.

East, R., Hammond, K., \& Lomax, W. (2008). Measuring the impact of positive and negative word of mouth on brand purchase probability. Prisma Social, 25, 215-224. https://doi.org/10.1016/j. ijresmar.2008.04.001.

Fehr, R., \& Gelfand, M. J. (2010). When apolo-gies work: How matching apology compo-nents to victims' self-construals facilitates forgiveness. Organizational Behavior and Human Decision
Processes, 113(1), 37-50. https://doi.org/10.1016/ j.obhdp.2010.04.002.

Grégoire, Y., Tripp, T. M., \& Legoux, R. (2009). When customer love turns into lasting hate: The effects of relationship strength and time on customer revenge and avoidance. Journal of Marketing, 73(6), 18-32. https://doi.org/10.1509/ jmkg.73.6.18.

Jin, D., Nicely, A., Fan, A., \& Adler, H. (2019). Joint effect of service recovery types and times on customer satisfaction in lodging. Journal of Hospitality and Tourism Management, 38, 149-158. https://doi.org/10.1016/j.jhtm.2019.01.005.

Joireman, J., Grégoire, Y., \& Tripp, T. M. (2016). Customer forgiveness following service failures. Current Opinion in Psychology, 10, 76-82. https://doi.org/10.1016/j.copsyc.2015.11. 005

Kwon, S. Y., \& Jang, S. C. S. (2012). Effects of compensation for service recovery: From the equity theory perspective. International Jour-nal of Hospitality Management, 31(4), 1235-1243. https://doi.org/10.1016/j.ijhm.2012.03.002.

Lai, M. C., \& Chou, F. S. (2015). The relation-ships among involvement level, service fail-ure, service recovery disconfirmation and cus-tomer lifetime value. Journal of Economics, Business and Management, 3(4), 452-457. https://doi.org/ 10.7763/JOEBM.2015.V3.227.

Lazare, A. (2007). On apology. New York: Oxford University Press.

Liao, H. (2007). Do it right this time: The role of employee service recovery performance in customer-perceived justice and customer loyalty after service failures. Journal of Applied Psychology, 92(2), 475-489. https://doi.org/10.1037/ 0021-9010.92.2.475.

Maxham, J. G., \& Netemeyer, R. G. (2002). A longitudinal study of complaining customers' evaluations of multiple service failures and recovery efforts. Journal of Marketing, 66(4), 57-71. https://doi.org/10.1509/jmkg.66.4.57. 18512.

Miller, J. L., Craighead, C. W., \& Karwan, K. R. (2000). Service recovery: A framework and empirical investigation. Journal of Operations Management, 18(4), 387-400. https://doi.org /10.1016/S02726963(00)00032-2.

Nunes, M. C. L., \& Lucian, R. (2014). A study on the influence of word of mouth commu-nication in the facebook audience of restau-rants. International Business Research, 7(11), 1-23. https://doi. org/10.5539/ibr.v7n11p1.

O'Hara, E. A. (2002). On apology and Con-silience. Washington Law Review, 77, 1121-1192. 
Okimoto, T. G., \& Tyler, T. R. (2007). Is compensation enough? Relational concerns in responding to unintended inequity. Group Processes \& Intergroup Relations, 10(3), 399-420. https://doi. org/10.1177/1368430207078701.

Özdemir, A., Tozlu, E., Şen, E., \& Ateşoğlu, H. (2016). Analyses of word-of-mouth communication and its effect on students' university preferences. Procedia - Social and Behavioral Sciences, 235(October), 22-35. https://doi.org /10.1016/j.sbspro.2016.11.022.

Park, J. J., \& Park, J. W. (2016). Investigating the effects of service recovery quality elements on passengers' behavioral intention. Journal of Air Transport Management, 53, 235-241. https://doi. org/10.1016/j.jairtraman.2016.03.003.

Ranaweera, C., \& Prabhu, J. (2003). On the relative importance of customer satisfaction and trust as determinants of customer retention and positive word of mouth. Journal of Targeting, Measurement and Analysis for Marketing, 12(1), 82-90. https://doi.org/10.10 57/palgra ve.jt.5740100

Rashid, M., \& Ahmad, F. S. (2014). The role of recovery satisfaction on the relationship between service recovery and brand evangelism: A conceptual framework. Intern-ational Journal of Innovation, Management and Technology, 5(5), 401-405. https://doi.org/10.7763/IJIMT.2014. V5. 548

Sengupta, S., Ray, D., Trendel, O., \& Vaerenbergh, Y. Van. (2018). The effects of apologies for service failures in the global on-line retail. International Journal of Electronic Commerce, 22(3), 419-445. https://doi.org/10.1080/10864 415.2018.1462951.
Shi, W., Tang, L., Zhang, X., Gao, Y., \& Zhu, Y. (2016). How does word of mouth affect customer satisfaction? Journal of Business and Industrial Marketing, 31(3), 393-403. https://doi. org/10.1108/jbim-07-2014-0139.

Tax, S. S., Brown, S. W., \& Chandrashekaran, M. (1998). Customer evaluations of service complaint experiences: Implications for relation-ship marketing. Journal of Marketing, 62, 60-76. https://doi.org/10.2307/1252161.

Tomlinson, E. C., Dineen, B. R., \& Lewicki, R. J. (2004). The road to reconciliation: Ante-cedents of victim willingness to reconcile following a broken promise. Journal of Management, 30(2), 165-187.https://doi.org/10.1016/j.jm.2003.01.003

Tucker, S., Turner, N., Barling, J., Reid, E. M., \& Elving, C. (2006). Apologies and transformational leadership. Journal of Business Ethics, 63, 195-207. https://doi.org/10.1007/s10551005-3571-0.

Vázquez-Casielles, R., Suárez-Álvarez, L., \& del RíoLanza, A. B. (2013). The word of mouth dynamic: How positive (and negative) wom drives purchase probability: An analysis of interpersonal and non-interpersonal factors. Journal of Advertising Research, 53(1), 43-60. https://doi. org/10.2501/JAR-53-1-043060.

Voyer, P. A., \& Ranaweera, C. (2015). The im-pact of word of mouth on service purchase decisions: Examining risk and the interaction of tie strength and involvement. Journal of Service Theory and Practice, 25(5), 636-656. https://doi.org/10.1108/ JSTP-04-2014-0070.

Wanke, M. (2008). Social Psychology of Consu-mer Behavior. In M. Wanke (Ed.), Advances in Consumer Research. New York: Psychology Press.

Wirtz, J., \& Lovelock, C. (2018). Essentials of Services Marketing (3rd ed.). England: Pear son. 